\title{
Çocukluk Dönemi Yürütücü İşlevler Envanteri Türkçe Formunun 48-72 aylık çocuklar için geçerlik ve güvenirlik çalışması*
}

\author{
The validity and reliability study of the Turkish version of Childhood \\ Executive Functioning Inventory for 48-72-month-old children
}

\section{Makale Geçmişi \\ Geliş : 17 Mavıs 2020 \\ Düzeltme : 25 Ağustos 2020 \\ Kabul : 3 Ekim 2020}

\section{Makale Türü}

Arastırma Makalesi
Article History

Received : 17 May 2020

Revised : 25 August 2020

Accepted : 3 October 2020

Article Type

Research Article
Hande Arslan Çiftçi ${ }^{1}$, Gülden Uyanık ${ }^{2}$ İbrahim H. Acar ${ }^{3}$
Öz: Bu araştırmanın amac1, Çocukluk Dönemi Yürütücü İşlevler Envanteri (ÇDYİE) (CHEXI; Thorell ve Nyberg, 2008) Türkçe öğretmen formunun 48-72 aylık çocuklar için geçerlik ve güvenirlik çalışmasını gerçekleştirmektir. Çalışma grubu, İstanbul ilindeki 48 okuldan ve 180 sinıftan, 48-72 aylık toplam 754 çocuktan oluşmaktadır. ÇDYİE Türkçe formu özgün ölçekte olduğu gibi 24 maddeden oluşmuştur ve doğrulayıcı faktör analizi iki faktörlü (Çalışan Bellek ve Ketleyici Kontrol) orijinal yapıyı desteklemiştir $(\chi 2(544)=1113.891, \mathrm{CFI}=0.93, \mathrm{RMSEA}=0.06[\% 90 \mathrm{CI} 06,07], \mathrm{SRMR}=0.04)$. Faktör yük değerlerinin 0.47 ile 0.85 arasında değiştiği gözlenmiştir. Ölçeğin ölçüt bağıntılı geçerliğini belirlemek amacıyla kullanılan Çocuk Davranış Değerlendirme Ölçeği ile Çalışan Bellek alt ölçeği $(r=0.83, p<0.001)$ ve Ketleyici kontrol alt ölçeği $(r=0.77, \mathrm{p}<0.001)$ puanları arasında pozitif yönlü anlamlı korelasyon katsayıları elde edilmiştir. Cronbach's alpha katsayıları, Çalışan Bellek alt ölçeği için 0.95 ve Ketleyici Kontrol alt ölçeği için 0.91 olarak bulunmuştur. Test-tekrar test güvenirlik katsayısı ise Çalışan Bellek için 0.89 ve Ketleyici Kontrol için 0.85 olarak bulunmuștur. Düzeltilmiș madde-toplam puan korelasyonları ise 0.46 ile 0.83 arasında değişmektedir. Sonuçlar, ÇDYİE Türkçe formunun 48-72 aylık çocukların yürütücü işlevlerini değerlendirmede geçerli ve güvenilir bir ölçme aracı olduğu ortaya konmuştur.

Anahtar Kelimeler: Çalışan bellek, derecelendirme ölçeği, ketleyici kontrol, okul öncesi çocukları, yürütücü işlevler.

\begin{abstract}
The aim of this research is to carry out reliability and validity studies of the Childhood Executive Functioning Inventory (CHEXI; Thorell \& Nyberg, 2008) Turkish teacher form for 48-72 months old children. The study group included 48-72 months old 754 children from 48 schools and 180 classrooms in Istanbul. Turkish form of CHEXI consisted of 24 items like in the original scale, and confirmatory factor analysis supported the original two-factor (working memory and inhibitory control) structure $[\chi 2(544)=1113.891, \mathrm{CFI}=0.93, \mathrm{RMSEA}=0.06(90 \% \mathrm{CI} 06,07), \mathrm{SRMR}=0.04]$. It was observed that factor load values ranged between 0.47 and 0.85 . To determine the scale's criterion validity, the 'Child Behaviour Rating Scale (CBRS)' was used. It was found a positive significant relationship between CBRS and Working Memory subscale $(\mathrm{r}=0.83, \mathrm{p}<0.001)$ and Inhibitory Control subscale $(\mathrm{r}=0.77, \mathrm{p}<0.001)$ scores. Cronbach's alpha coefficient was found as 0.95 for Working Memory and 0.91 for Inhibitory Control subscale. Test-retest reliability coefficient was found as 0.89 for Working Memory and 0.85 for Inhibitory Control subscale. Corrected item-total correlations ranged from 0.46 to 0.83 . Results show that the CHEXI Turkish form is a reliable and valid scale to evaluate 48-72 months old children's executive functions.
\end{abstract}

Keywords: Executive functions, inhibitory control, preschool children, rating scale, working memory.

\footnotetext{
Başlıca Yazar: Hande Arslan Çiftçi

*Bu makale, Hande ARSLAN ÇIFTÇI’nin Prof. Dr. Gülden UYANIK ve Doç. Dr. İbrahim H. Acar danıșmanlığındaki doktora tezinin bir kısmından üretilmiştir ve 10-13 Eylül tarihleri arasında sanal ortamda gerçekleştirilen VII ${ }^{\text {th }}$ International Eurasian Educational Research Congress'te “sözlü bildiri”" olarak sunulmuştur.

${ }_{1}^{1}$ İstanbul Medeniyet Üniversitesi, Eğitim Bilimleri Fakültesi, Temel Eğitim Bölümü, hande.arslan@medeniyet.edu.tr, ORCID: http://orcid.org/0000-0001-5061-3882

2 Marmara Üniversitesi, Atatürk Eğitim Fakültesi, Temel Eğitim Bölümü, guyanik@marmara.edu.tr, ORCID: http://orcid.org/0000-0001-99478159

3 Özyeğin Üniversitesi, Sosyal Bilimler Fakültesi, Psikoloji Bölümü, ibrahim.acar@ozyegin.edu.tr, ORCID: http://orcid.org/0000-0003-40075691
} 


\section{SUMMARY}

\section{Introduction}

Assessment of executive functions of preschool children is important because of the role that executive functions play in facilitating development in areas such as academic skills, cognitive and social-emotional development, and healthy psychological functionality (e.g., Best, Miller \& Jones, 2009). Unlike the rating scales of other executive functions, Childhood Executive Functioning Inventory (CHEXI; Thorell \& Nyberg, 2008) was developed specifically to focus on executive function skills rather than more general expressions or items directly related to attention deficit hyperactivity disorder's (ADHD) diagnostic criteria. When it is desired to measure how executive functions relate to other structures, a more specifically focused measurement tool such as CHEXI is required. The aim of this study is to carry out the validity and reliability study of the Turkish form of CHEXI for 48-72 months old children. Besides the psychometric features of the CHEXI, it was also examined whether the children's executive functions differ in terms of their age and gender. CHEXI was adapted to Turkish before; its validity and reliability were examined for the first- and second-grade primary school children $(n=132)$, and the first data were obtained (Kayhan, 2010). In this study, it is aimed to evaluate the psychrometric features of CHEXI Turkish form in a more comprehensive sample that includes preschool children and in more detail.

\section{Method}

The study group included 48-72-month-old 754 preschool children who continue their education in 48 schools (15 private and 33 public) and 180 classrooms of the Ministry of National Education in 10 districts on Europe and Asia side of Istanbul in 2018-2019 school year.

The maximum variety method, which is one of the purposeful sampling types, was used in the selection of the sample. Accordingly, schools have been selected to reflect the lower, middle, and upper socio-cultural level (McMillan \& Schumacher, 2006). Whilst 49.6\% ( $n=374)$ of the children are girls, $50.4 \%(n=380)$ are boys. While $42.3 \%(n=319)$ of the children are 48-60 months old, $57.7 \%(n=435)$ are $61-72$ months old. The average age of the group is 61.01 months $(S=6.99)$.

CHEXI was developed by Thorell and Nyberg (2008) as a measurement tool that focuses on children's executive functions. The questions in the scale were based on Barkley's (1997) model. Although CHEXI was developed with four factors in mind (working memory, planning, inhibition and regulation), the twofactor structure - working memory and inhibition - was found to be the best fit to the data evaluated by both parents and teachers (Thorell \& Nyberg, 2008). CHEXI consists of 24 items. In this study, to determine the scale's criterion validity, 'Child Behaviour Rating Scale (CBRS)' (Bronson, Goodson, Layzer \& Love, 1990; adapted into Turkish by Sezgin \& Demiriz, 2016) which is the behaviour regulation subscale was used. 


\section{Results}

It was found that corrected item-total correlations ranged from 0.46 to 0.83 . According to the t-test results between the upper $27 \%$ and lower $27 \%$ groups, the differences were significant for all items and subscale total scores $(\mathrm{p}<0.001)$ and $\mathrm{t}$ values were between 30.96 and 64.78 .

Two-factor confirmatory factor analysis (CFA) measurement model was applied using Mplus (Muthen \& Muthen, 2012) to examine the acceptability of the two-factor original model of the scale. In addition, to test whether this two-factor structure differs according to the age of the children, CFA models were made with the help of the Mplus grouping method for these two age groups (48-60 months and 61-72 months). First of all, comparative fit index (CFI; Bentler, 1995), root mean square error of approximation (RMSEA; Brown \& Cudeck, 1992) and standardized root mean square residual (SRMR; Bentler, 1995; Hu \& Bentler, 1999) were used to test the compatibility of the model with the available data. In this study, first, the CFA model was tested for the entire sample group. Looking at the fit indices, this model was found to be in good agreement with the data $\left[\chi^{2}(544)=1113.891, \mathrm{CFI}=0.93, \mathrm{RMSEA}=0.06(90 \%\right.$ CI 06, 07) and SRMR $=0.04]$. In addition, the model, which includes the age groups of 4 and 5 , was found to be in good agreement with the data $\left[\chi^{2}(544)=1595.225, \mathrm{CFI}=0.91, \mathrm{RMSEA}=0.07(90 \% \mathrm{CI} 06,07)\right.$ and $\mathrm{SRMR}=$ 0.05]. CFA loads found for all sample and age groups were loaded to specified subscales significantly. It was observed that factor load values vary between 0.47 and 0.85 .

To determine the scale's criterion validity, the 'Child Behavior Rating Scale (CBRS)' was used. It was found a positive significant relationship between CBRS and working memory subscale $(r=0.83, p<0.001)$ and inhibitory control subscale $(r=0.77, p<0.001)$ scores. To examine the reliability of the CHEXI-Turkish form, the methods of Cronbach's alpha internal consistency and test-retest were employed. Cronbach's alpha was found as 0.95 for working memory and 0.91 for inhibitory control subscale. In addition, testretest reliability coefficient was found as 0.89 for working memory and 0.85 for inhibitory control subscale.

In addition, it was found that the girls showed higher scores in both working memory $[t(746)=5.08$, $p<0.001, d=0.37]$ and inhibitory control $[t(747)=6.36, p<0.001, d=0.46]$ subscales than boys. It was also found that 48-60-month-old children showed lower scores in both working memory $(t(752)=5.15$, $p<0.001, d=0.38)$ and inhibitory control subscales $[t(752)=4.26, p<0.001, d=0.31]$ than $61-72$-monthold children.

\section{Conclusion and Discussion}

In this study, it was revealed that the Turkish version of CHEXI consisting of 24 items in two subscales is a valid and reliable measurement tool for evaluating the executive function skills of 48-72-month-old children. Since the scale is short, easily applicable, and free of charge, it is thought that it will meet an important need in future research aiming to examine the executive function skills of preschool children. CHEXI can be used in both research and clinical settings. In addition, it can be used to identify children in risk groups related to executive functions and to direct intervention practices. 


\section{GİRIŞ}

Yürütücü işlevler, hedefe yönelik, etkili ve uyarlanabilir (sosyal) davranışlar için gerekli olan bilişsel süreçleri içermektedir. Bu yüzden de günlük davranışta önemli bir rol oynamaktadır. Yürütücü işlevlerle ilgili sorunlar, dürtüsel davranışta, ileriyi planlamada ve davranışı değişen koşullara uyarlamada zorluk yaşama olarak ortaya çıkabilir. Bu zorluklar da çocuğun günlük işleyişini engelleyebilir (Huizinga ve Smidts, 2011). Yürütücü işlevlerin erken çocukluk dönemindeki gelişimi, bilimsel ve pedagojik ilginin artmasıyla güncel bir konu haline gelmiştir (Griffin, Freund, McCardle, DelCarmen-Wiggins ve Haydon, 2016). Dolayısıyla, son y1llarda yürütücü işlevler ve eğitim çıktılarına uygulamaları üzerine araştırmalar artmıştır.

Yürütücü işlevlerin gelişimi uzun sürelidir: bebeklik döneminde ortaya çıkar, erken çocukluk döneminde hızlı bir büyüme yaşar, geç ergenlikte olgunlaşır ve geç yetişkinlikte kötüleşir (Diamond, 2013). Araştırmalar, yürütücü işlev becerilerinin 3-7 yaş arasında hızla geliştiğini ve erken yetişkinliğe kadar uzun bir süreç boyunca gelişimini sürdürdüğ̈nü göstermektedir (Diamond, 2013; Senn, Espy ve Kaufmann, 2004). Hughes, Ensor, Wilson ve Graham (2010) tarafindan yapilan bir çalışmada, yürütücü işlev becerilerinin yürütücü işlev görev puanlarındaki artışlarda, büyük bireysel farklılıklarla birlikte, 4 ila 6 yaş arasında ortalama iki standart sapma büyüdüğü bulunmuştur. Ayrıca, 3 ila 5 yaşları arasındaki yürütücü işlevleri inceleyen bir başka çalışmada, bu dönemde yürütücü işlev yeteneğindeki toplam değişimin \%60'ının 4 ila 5 yaşları arasında meydana geldiği bildirilmiştir (Willoughby, Blair, Wirth, Greenberg ve The Family Life Project Investigators, 2012).

\section{Yürütücü İşlevlerin Tanımı}

Yürütücü işlevler, insanların kendi düşüncelerini ve eylemlerini kontrol etmelerini ve davranışlarını uzun vadeli hedeflere yönlendirmelerini sağlayan üst düzey nörobilişsel beceriler olarak ifade edilmektedir (Carlson, Zelazo ve Faja, 2013; Hendry, Jones ve Charman, 2016; Zelazo ve Carlson, 2012). Küçük çocukların yeni zorluklarla başa çıkabilmeleri, cezbedici ve dikkat dağıtıcı şeylere direnmeleri, akıl yürütmeleri ve problemleri çözmeleri için bu üst düzey zihinsel süreçlere ihtiyaçları vardır (Diamond, 2013). Yürütücü işlevlerin farklı kavramsallaştırmaları mevcut olsa da temel yürütücü işlev becerileri bilişsel esneklik, çalışan bellek ve ketleyici kontrolü içermektedir (Blair ve Diamond, 2008; Carlson ve diğerleri, 2013; Diamond, 2013; Garon, Bryson ve Smith, 2008; Hughes, 2011; Meuwissen ve Zelazo, 2014). Bu beceriler, yürütücü işlevlerin ana bileşenleri olarak kabul edilmektedir (Miyake ve diğerleri, 2000). Bunlar, aynı zamanda yürütücü işlevin erken çocukluk döneminde en sık çalışılan üç alanıdır (Garon ve diğerleri, 2008). Planlama, akıl yürütme ve problem çözme gibi diğer beceriler, ileri seviye yürütücü işlevler olarak kabul edilir ve bu üç 
temel beceriden ortaya çıkar (Diamond, 2013). Bu üç beceri, prefrontal korteksteki bölgeleri ve beynin diğer alanlarını içeren sinir devrelerine dayanmaktadır ve bu nedenle nörobilişsel beceriler olarak tanımlanabilir. Bu beceriler, bir hedefe ulaşmak için aktif ve kasıtlı olarak dikkati kontrol etmenin bir yoludur (Zelazo, Blair ve Willoughby, 2016). Bu çekirdek üç yürütücü işlevin birbirinden bağımsız fakat birbiriyle ilişkili olduğu varsayılmıştır. Son nörogörüntüleme çalışmaları bu modeli destekleme eğilimindedir; üç bileşenin bağımsız beyin alanları ile ilişkili olduğu ancak aktivasyon alanlarını da paylaştığı bulunmuştur (Collette ve diğerleri, 2005; McNab ve diğerleri, 2008). Diğer bir ifadeyle, üniter bir yapının aksine, birbiriyle ilişkili ancak ayrı yürütücü işlev bileşenlerinin olduğu teorik model, araştırmaları önemli ölçüde etkilemiş ve genel fikir birliği kazanmıştır (Diamond, 2013).

Bu üç bileşenden çalışan bellek, kısa süre boyunca farklı bilgileri akılda tutma ve onlarla çalışma kapasitesini içerir (Neitzel, 2018). Çalışan bellek (bilgiyi akılda tutmak ve manipüle etmek) kısa süreli bellekten (sadece bilgiyi akılda tutmak) farklıdır (Diamond, 2013). Çalışan bellek, zihinsel temsillerle çalışma yeteneğidir. Önceki ve yeni bilgiler arasında ilişkiler kurmak, ifadeleri anlamak ve açık olmayan bağlantılar kurmak için çok önemlidir (Diamond, 2012; 2013). Ketleyici kontrol ya da ketleme, görevleri tamamlamaya engel olan doğal ama gereksiz düşünceleri veya davranışları engelleme becerisini ifade etmektedir (McClelland, Cameron, Wanless ve Murray, 2007). Böylece, ketleyici kontrol, ana göreve odaklanmamızı sağlar ve duruma uygun olmayan otomatik cevaplar vermemizi önler (Diamond, 2013). Aynı zamanda, düşünce ve dürtülerle başa çıkmada ve onları filtrelemede ve harekete geçmeden önce durma ve düşünmede kullanılmaktadır (Neitzel, 2018). Ketleyici kontrol, ilk ortaya çıkan ve diğer iki bileşenin üzerine kurulduğu yürütücü işlev gibi görünmektedir (Diamond, 2016). Bilissel esneklik ya da dikkat transferi ise, iki veya daha fazla tepki alternatifi arasında geçiş yapabilme becerisidir (Davidson, Amso, Anderson ve Diamond, 2006). Bilişsel esneklik, değişen taleplere, önceliklere ve değişime uyum sağlamayı, bir şeyi yeni veya farklı bir bakış açısıyla değerlendirmeyi, bakış açıları arasında geçiş yapmayı, farklı ortamlar için farklı kurallar olduğunu anlamayı ve soyut düşünmeyi içermektedir (Neitzel, 2018; Nguyen ve Duncan, 2019). Bilişsel esneklik, ketleyici kontrol ve çalışan belleğin üzerine inşa edilir ve onların kullanılmasinı gerektirmektedir (Diamond, 2013).

\section{Küçük Çocuklarda Yürütücü İşlevlerin Değerlendirilmesi}

Klinik ortamlarda ve araştırma ortamlarında yürütücü işlev becerilerini değerlendirmek için hem performansa dayalı testler hem de derecelendirme ölçekleri (rating scales) kullanılmaktadır (Toplak, West ve Stanovich, 2013). Performansa dayalı yürütücü işlevlerin ölçümleri, çocuğun belirli 
görevlerde verdiği yanıtların doğruluğunu veya hızını değerlendirmek için genellikle bire bir uygulanan yüksek düzeyde standartlaştırılmış prosedürleri içermektedir (Steenbergen-Hu, Olszewski-Kubilius ve Calvert, 2017). Okul öncesinde yürütücü işlevlerin birçok performansa dayalı ölçümü vardır. Örneğin, ketleyici kontrol için Stroop benzeri olan "Gündüz-Gece görevi”" (Gerstadt, Hong ve Diamond, 1994), çalışan bellek için “Ters Sayı Dizisi etkinliği” (Davis ve Pratt, 1995) ve bilişsel esneklik için "Boyutsal Değişim Kart Sıralaması" (Doebel ve Zelazo, 2015) en çok kullanılan görevlerdir ve Türkiye'deki çalısmalarda da kullanıldığ1 görülmektedir (örn. Alp ve Özdemir, 2007; Oğuz ve Kara, 2018; Yıldız ve Akbaş, 2017). Ayrıca, yeni bir performansa dayalı ölçme aracı olarak okul öncesi dönem çocuklarının çalışan bellek, bilişsel esneklik ve ketleyici kontrollerinin birleşimini değerlendirmek için geliştirilen Baş-Ayak Parmakları-Dizler-Omuzlara Dokunma Yönergeleri (Ponitz, McClelland, Matthews ve Morrison, 2009)'nin hem yurtdışı hem de ülkemizdeki alanyazında son y1llarda sıklıkla kullanıldığ1 görülmektedir (örn., McClelland ve Cameron, 2012; McClelland vd., 2014; Sezgin ve Demiriz, 2019; Tuncer, 2018).

Okul öncesi dönem çocukları için kullanılan derecelendirme ölçekleri ise çocuğun günlük ve problem çözme durumlarındaki yürütücü işlev becerilerini ebeveyn veya öğretmenin verdiği yanıtlarla değerlendirir (Roth, Isquith ve Gioia, 2005). Değerlendirici yanlllığı, derecelendirme ölçekleri kullanılırken her zaman dikkate alınması gereken bir konudur (Denckla, 2002). Öte yandan, derecelendirme ölçekleri uzun bir süre boyunca davranışı yakalama avantajına sahiptir ve uygulanması kolay olduğundan, risk altındaki çocukları tanımlamak için bir tarama aracı olarak kullanımda çok faydalıdırlar (Thorell ve Nyberg, 2008). Bugüne kadar, okul öncesi dönem çocuklarda yürütücü işlevler sorunlarını daha günlük bir bakış açısından ölçmek için geliştirilmiş sadece iki standart psikometrik ölçme aracı son zamanlarda kullanıma sunulmuştur. Bunlar, Yürütücü İşlevler Davranış Derecelendirme Envanteri (BRIEF-P; Gioia, Isquith, Guy ve Kenworthy, 2000) ve Çocukluk Dönemi Yürütücü İşlevler Envanteri (CHEXI; Thorell ve Nyberg, 2008)'ni içermektedir. Buna ek olarak, 1990 yllında geliştirilmiş Çocuk Davranış Değerlendirme Ölçeği (Child Behavior Rating Scale-CBRS; Bronson, Goodson, Layzer ve Love, 1990)'nin Davranış Düzenleme alt boyutu yürütücü işlev alanlarını değerlendiren maddeleri kapsamaktadır. Ayrıca, çocukluk mizacını araştırmaya yönelik olsa da Çocuk Davranış Listesi (CBQ)'nin bir kısmı da yürütücü işlev davranışları açısından yorumlanabilir, çünkü aynı zamanda ketleyici kontrol, dürtüsellik ve odaklanma yeteneğini de ölçen alt ölçekler bulunmaktadır (Rothbart, Ahadi, Hershey ve Fisher, 2001). Bu ölçme araçları Türkçeye uyarlanmıştır ve alanda kullanılmaktadır (Örn., Acar ve diğerleri, 2018; Erdoğan Bakar, Taner, Soysal, Karakaş ve Turgay, 2011; Öğütcen, 2020, Sezgin ve Demiriz, 2019). 
Yürütücü İşlevler Davranış Derecelendirme Envanteri (BRIEF; Gioia ve diğerleri, 2000) çocukların yürütücü işlev becerilerini ölçmede en yaygın olarak kullanılan derecelendirme ölçeğidir. BRIEF, ebeveyn, öğretmen ve öğrenci formlarını içerir ve okul öncesi yaştaki çocuklarla kullanılmak üzere değiştirilmiş ve BRIEF-P adını almıştır (Gioia, Espy ve Isquith, 2003). BRIEF-P, çocukların altta yatan bilişsel yeteneklerinin davranışsal dışavurumlarını yansıttığı varsayılan ev ve okul öncesi bağlamlarda gözlemlenebilir davranışları ölçmektedir (Isquith, Roth ve Gioia, 2013). Güçlü yönlerine rağmen, BRIEF-P nispeten uzundur (68 madde) ve protokol ve puanlama dâhil olmak üzere uygulama başına 2 ABD dolarından fazla maliyeti vardır. Bu faktörler, BRIEF-P'nin düşük kaynağa sahip araştırmalarda ve ortamlarda kullanılmasını engel olmaktadır (Camerota, Willoughby, Kuhn ve Blair, 2018). Bununla birlikte, mevcut yürütücü işlev ölçeklerinin (BRIEF-P ve CBQ) ciddi bir sınırlaması, sadece çalışan bellek ve ketleyici kontrol gibi farklı yürütücü işlev yapılarını ölçen maddeleri değil, aynı zamanda dikkat eksikliği ve hiperaktivite bozukluğu (DEHB) için tanı ölçütleriyle neredeyse aynı olan maddeleri de içermesidir. Örneğin, BRIEF-P ölçme aracında, çalışan bellek alt ölçeği sürdürülen dikkati ölçen maddeleri de içerdiğinden (örneğin, "kisa bir dikkat süresine sahiptir”), DEHB olan çocuklar, bu alt ölçekte yüksek puanlar alabilirler ama bu düşük çalısan bellek becerileri olduğunu göstermez (Thorell, Eninger, Brocki ve Bohlin, 2010).

Diğer yürütücü işlev derecelendirme ölçeklerinden farklı olarak, Çocukluk Dönemi Yürütücü İşlev Envanteri-ÇYDİE (CHEXI; Thorell ve Nyberg, 2008), DEHB'nin tanı ölçütleriyle doğrudan ilgili daha genel ifadeler veya maddeler yerine, özellikle yürütücü işlev becerilerine odaklanmak amaciyla geliştirilmiştir. Yürütücü işlevlerin, diğer yapılarla nasıl ilişkili olduğu ölçmek istendiğinde, yürütücü işlev becerilerine ÇYDİE gibi daha spesifik olarak odaklanan bir ölçme aracı gereklidir. Nispeten yeni bir ölçme aracı olan ÇYDİE, 24 maddeye sahiptir ve bu nedenle BRIEF-P'den daha kısadır; aynı zamanda kullanmak isteyen herkese açıktır ve birden çok dile çevrilmiştir (bkz. http://ww.chexi.se). ÇYİDE, dört faktör göz önünde bulundurularak tasarlanmış olsa da (çalışan bellek, planlama, ketleyici kontrol ve düzenleme), iki faktörlü yapının-çalışan bellek ve ketleyici kontrol- hem ebeveyn hem de öğretmen tarafindan değerlendirilen verilere en iyi uyumu sağladığ1 bulunmuştur (Thorell ve Nyberg, 2008). Ayrıca, iki faktörlü yap1 diğer çalışmalarda da tekrarlanmıştır (Camerota ve diğerleri, 2018; Catale, Lejeune, Merbah ve Meulemans, 2013; Catale, Meulemans ve Thorell, 2013; Kayhan, 2010).

\section{Çalı̧̧manın Amacı}

Okul öncesi dönem çocuklarının yürütücü işlevlerinin değerlendirilmesi, yürütücü işlevlerin akademik beceriler, bilişsel ve sosyal-duygusal gelişim ve sağlıklı psikolojik işlevsellik gibi alanlarda 
gelişmeyi kolaylaştırmada oynadığı rol nedeniyle önemlidir (örn., Best, Miller ve Jones, 2009). Bu çalışmanın amacı, Çocukluk Dönemi Yürütücü İşlev Envanteri-ÇDYİE (CHEXI; Thorell ve Nyberg, 2008) Türkçe öğretmen formunun 48-72 aylık çocuklar için geçerlik ve güvenirlik çalışmasını gerçekleştirmektir. ÇDYİE'nin psikometrik özelliklerine ek olarak, çocukların yürütücü işlevlerinin yaş ve cinsiyet bakımından farklılaşıp farklılaşmadığı da incelenmiştir. ÇDYİE, Türkçeye daha önce uyarlanarak 1. ve 2. sınıf ilkokul çocukları ( $n=132)$ için geçerlik ve güvenirliği incelenmiş ve ilk veriler elde edilmiştir (Kayhan, 2010). Bu çalışmada ise ÇYDİE Türkçe formunun okul öncesi dönem çocuklarını dahil eden daha kapsamlı bir örneklemde ve psikometrik özelliklerinin daha ayrıntılı bir biçimde değerlendirilmesi hedeflenmektedir.

\section{YÖNTEM}

\section{Çalışma Grubu}

Araştırmanın çalışma grubunu 2018-2019 eğitim ve öğretim yllının Güz döneminde, İstanbul ili Avrupa yakasından Güngören, Küçükçekmece, Saryyer, Bayrampaşa ve Beşiktaş ilçeleriyle, Asya yakasından Maltepe, Çekmeköy, Ataşehir, Kadıköy ve Tuzla ilçelerindeki Millî Eğitim Bakanlığı'na bağl1 15 özel, 33 devlet olmak üzere toplam 48 okuldan ve 180 sınıftan, 48-72 aylık 754 çocuk oluşturmuştur. Bu 48 okulda çalışan 180 okul öncesi öğretmeni, sınıflarındaki çocukları ÇDYİE ile değerlendirmişlerdir.

Örneklemin seçiminde, amaçsal örnekleme çeşitlerinden maksimum çeşitlilik yöntemi kullanılmıştır. Buna göre, okulların alt, orta ve üst sosyo-ekonomik düzeyi yansıtacak şekilde seçilmesine özen gösterilmiştir (McMillan ve Schumacher, 2006). Çalışmaya katılan çocukların \%49.6’sı ( $\mathrm{n}=374) \mathrm{k} 1 \mathrm{z}, \% 50.4$ 'ü $(\mathrm{n}=380)$ erkektir. Çocukların aylara göre dağılımları incelendiğinde \%42.3’ü (n=319) 48-60 aylık, \%57.7'si (n=435) de 61-72 aylıktır. Grubun yaş ortalaması 61.01 aydır ( $\mathrm{S}=6.99)$. Çalışma grubuna ilişkin demografik bilgiler Tablo 1'de gösterilmiştir.

Ayrıca, çocukları değerlendiren 180 okul öncesi öğretmeninin hepsi kadındır ve 4’ü (\%2.2) meslek lisesi, 27'si (\%15) ön lisans, 127'si (\%70.6) lisans, 18’i (\%10) yüksek lisans ve 4’ü (\%2.2) doktora mezunudur. Öğretmenlerin kıdem yıllarına bakıldığında, öğretmenlerin 50’si (\%27.8) 0-5 yıl, 53’ü (\%29.4) 6-10 yll, 41’i (\%22.8) 11-15 yıl, 20’si (\%11.1) 16-20 yıl ve 16’s1 da (8.9) 21 ve üstü yıldır öğretmen olarak çalışmaktadır. 
Tablo 1. Çalışma grubunun demografik özellikleri

\begin{tabular}{llll}
\hline & & $\mathrm{N}$ & $\%$ \\
\hline Yaş & $48-60$ ay & 319 & 42.3 \\
& $61-72$ ay & 435 & 57.7 \\
\hline Cinsiyet & Kiz & 374 & 49.6 \\
& Erkek & 380 & 50.4 \\
\hline Anne eğitim durumu & Okuma-yazma bilmiyor & 2 & 0.3 \\
& Okula gitmemiş okuryazar & 5 & 0.7 \\
& Ilkokul & 74 & 9.8 \\
& Ortaokul & 63 & 8.3 \\
& Lise & 207 & 27.4 \\
& Üniversite & 382 & 50.7 \\
& Cevap yok & 21 & 2.8 \\
\hline Baba eğitim durumu & Okuma-yazma bilmiyor & 1 & 0.1 \\
& Okula gitmemiş okuryazar & 3 & 0.4 \\
& Ilkokul & 60 & 8 \\
& Ortaokul & 80 & 10.6 \\
& Lise & 183 & 24.3 \\
& Üniversite & 395 & 52.4 \\
Aile sosyo-ekonomik düzey* & Cevap yok & 32 & 4.2 \\
\hline Okul öncesi eğitimden faydalanma durumu & Alt & 219 & 29 \\
& Orta & 311 & 41.3 \\
& Üst & 224 & 29.7 \\
\hline
\end{tabular}

* Öğretmenler rapor etmiştir.

\section{Veri Toplama Araçları}

\section{Demografik Bilgi Formu}

Araştırmacılar tarafindan oluşturulan demografik bilgi formunda çocukların yaş, cinsiyet, anne ve babanın eğitim durumu gibi demografik bilgileri (bkz. Tablo 1) sorulmuştur. Form, çocukların okulunda bulunan dosyalarındaki bilgiler doğrultusunda öğretmenleri tarafindan doldurulmuştur.

\section{Çocukluk Dönemi Yürütücü İslevler Envanteri (ÇDYIEE)}

Çocukluk Dönemi Yürütücü İşlev Envanteri-ÇDYİE (Childhood Executive Functioning Invantery-CHEXI), Thorell ve Nyberg (2008) tarafindan, 4-12 yaş arası çocukların yürütücü işlevlerine odaklanan bir ölçme aracı olarak geliştirilmiştir. Ölçekte yer alan sorular, ketleyici kontrol, çalışan bellek ve öz-düzenlemenin DEHB olan çocuklarda önemli yürütücü işlev bozuklukları oluşturduğunu açıklayan Barkley (1997)'in modeline dayanarak oluşturulmuştur.

Ölçek geliştirilirken başlangıçta 26 madde 4 alt boyut içerisinde kategori edilmiştir. Buna göre, 11 madde "çalışan bellek", 4 madde "planlama", 6 madde "ketleyici kontrol" ve beş madde de “düzenleme" alt boyutu altında düşünülmüştür. Ancak, 25. ve 26. madde, çok düşük örneklem uygunluğu gösterdiği için faktör analizine alınmamıştır. Faktör analizi sonuçlarına göre, iki faktörlü yapının verilere en iyi uyumu sağladığı bulunmuştur: (1) çalışan bellek ve (2) ketleyici kontrol. İlk 
faktör, çalışan bellek ve planlama alt boyutlarının maddelerini içerirken, ikinci faktör ise, ketleyici kontrol ve düzenleme alt boyutlarının maddelerini içermiştir. Buna ek olarak, iki faktör arasındaki korelasyon 0.65 olarak bulunmuştur. Bütün bu analizler önce envanterin ebeveyn formu için gerçekleştirilmiştir. Öğretmen formu ile yapılan çalışmada da iki faktörlü yapı ortaya çıkmıştır. Öğretmen değerlendirmelerinde ise, iki faktör arasındaki korelasyon 0.69 olarak bulunmuştur (Thorell ve Nyberg, 2008).

Sonuç olarak, ÇYDİE 24 maddeden oluşmaktadır. Alt ölçeklerden Çalışan Bellek 13 madde (örn., "Bir etkinliğin ortasındayken, ne yapıyor olduğunu hatırlamada zorluk yaşar") Ketleyici kontrol ise 11 madde (örn., "Söylenilmesine rağmen, kendini tutmakta veya zapt etmekte zorluk yaşar”) içermektedir. Ölçek, ebeveynler veya öğretmenler tarafindan doldurabilir. Ölçek, 5’li Likert tipindedir. Öğretmen veya ebeveyn, verilen ifadenin çocuk için ne kadar doğru olduğunu her ifadeden sonra yer alan sayılardan (1'den 5'e kadar) birini daire içine alarak belirtirler (1: Kesinlikle doğru değil, 5: Kesinlikle doğru). Ölçeğin doldurulması 5-10 dakika sürmektedir (Thorell ve Catale, 2014; Thorell ve Nyberg, 2008).

Ölçekten alınan yüksek puanlar, çocuğun yürütücü işlevler ile ilgili daha fazla zorluk yaşadığını göstermektedir. Dolayısıyla, envanterden düşük puan alan çocuklar, yüksek puan alanlara göre daha yüksek düzeyde yürütücü işlevlere sahiptirler yorumunda bulunulabilir (Thorell ve Nyberg, 2008). Ancak, bu çalışmada daha yüksek puanların yürütücü işlev zorlukları yerine yürütücü işlev becerilerinde artışı ifade etmesi için tüm maddeler ters kodlanmıştır, bu yüzden de yüksek puanlar çocuğun daha fazla yürütücü işlev becerileri gösterdiği anlamına gelmektedir.

ÇYDİE Türkçe formu Ek 1'de sunulmuştur.

\section{Çocuk Davranış Değerlendirme Ölçeği (ÇODDÖ)}

Çocuk Davranış Değerlendirme Ölçeği- ÇODDÖ (Child Behavior Rating Scale-CBRS), Bronson ve diğerleri (1990) tarafından 3-6 yaș çocukların öz-düzenleme becerilerini ölçmek amacıyla geliştirilmiştir. ÇODDÖ, öğretmenin sınıf ortamında çocukları değerlendirmek üzere kullanılan gözleme dayalı bir değerlendirme aracıdır (Bronson, Tivnan ve Seppanen, 1995).

Ölçek, 17 madde ve Davranış Düzenleme ve Sosyal Beceri olmak üzere iki alt boyuttan oluşmaktadır. Sosyal beceri alt boyutu, 7 maddeden oluşmaktadır ve sosyal becerilerle yönelik sorular içermektedir. Davranış düzenleme alt boyutu ise 10 maddeden oluşmaktadır ve dikkat, ketleyici kontrol ve çalışan bellek alanlarını değerlendiren soruları içermektedir. Ölçek, 5’li Likert tipindedir (1-Hiçbir zaman, 5-Her zaman) (Bronson ve diğerleri, 1995; Wanless, McClelland, Acock, Chen ve Chen, 2011). Bu çalışmada ölçüt bağıntılı geçerlik için sadece Davranış Düzenleme alt boyutu kullanılmıştır ve öğretmenler tarafindan doldurulmuştur. 
Ölçeğin Türkçe formunun geçerlik ve güvenirlik çalısması, Sezgin ve Demiriz (2016) tarafindan yapılmıştır. Doğrulayıcı faktör analizi sonucunda orijinal modelin kabul edilebilir düzeyde uyum verdiği görülmüsstür. Ölçeğin alt boyutlarına ilişkin Cronbach Alfa güvenirlik katsayısı, 0.84-0.96 aralığında bulunmuştur. Ölçeğin test tekrar test güvenirliği ise 0.75 olarak bulunmuştur (Sezgin ve Demiriz, 2016).

Bu araştırmadaki ÇDYİE'nin geçerlik ve güvenirlik çalışmasında ölçüt bağıntılı geçerlik için kullanılan ÇODDÖ Davranış Düzenleme alt boyutunun Cronbach alfa iç tutarlık katsayısı 0.96 olarak bulunmuştur.

\section{İşlem}

Çocukluk Dönemi Yürütücü İşlev Envanteri’nin Türkçe uyarlamasını yapmak için öncelikle ölçeği geliştiren araştırmacılardan biri olan Lisa Thorell ile elektronik posta ile iletişime geçilmiş ve gerekli izin alınmıştır. ÇDYİE'yi Türkçeye daha önce uyarlayarak 1. ve 2. sınıf ilkokul çocukları için geçerlik ve güvenirliği inceleyen Ezgi Kayhan ile de elektronik posta yoluyla iletişime geçilmiş ve Türkçe formun kullanımı için gerekli izin alınmıştır. Kayhan (2010), ölçeğin 26 maddelik versiyonunun geçerlik ve güvenirliğini kanıtlamıştır. Ancak, ölçeğin orijinalinde 2 madde (25. ve 26. madde) düşük örneklem uygunluğundan dolayı ölçekten çıkarıldığı ve uyarlamalarında da en çok 24 maddelik versiyonu kullanıldığı için (Thorell ve Catale, 2014), bu çalışmada okul öncesi dönem çocukları için ölçeğin 24 maddelik versiyonunun geçerlik ve güvenirlik analizleri gerçekleştirilmiştir.

$\mathrm{Bu}$ çalışmanın etik ve yasal sorumluluklarını yerine getirmek için Marmara Üniversitesi Sosyal Bilimler Araştırma Etik Kurulu'ndan etik onay ve İstanbul İl Milli Eğitim Müdürlüğü’nden resmi izin alınmıştır. Seçilen okulların müdür ya da müdür yardımcılarıyla görüşülerek araştırma hakkında bilgi verilmiştir. Daha sonra okuldaki okul öncesi öğretmenlerine de çalışma hakkında gerekli açıklamalar yapılmıştır. Bununla birlikte, çalışma grubundaki çocukların velilerinden çocuklarının çalışmaya katılmasını onayladığını beyan eden Veli Onay Formu alınmıştır. Çalışmaya katılmaya istekli gönüllü öğretmenlerden formları sınıf listesinde velisi araştırmaya katılmasını onaylayan ve normal gelişim gösteren ilk 2 erkek öğrenci ve 2 kı öğrenci (toplam 4 öğrenci) için doldurmaları istenmiştir. Her bir öğretmenin formu en fazla 5 çocuk için doldurmalarına özen gösterilmiştir.

Özgün çalışmada (Thorell ve Nyberg, 2008) ÇDYİE için tasarlanan iki faktörlü modelin Türk çocuklar için geçerli olup olmadığını görmek amacıyla Doğrulayıcı Faktör Analizi (DFA) yapılmıştır. DFA, önerilen bir teori ya da modeldeki değişkenler arasındaki ilişkinin test edilmesi, verilerinin önerilen modeli doğrulayıp doğrulamadığının kontrol edilmesi için kullanılmakta ve yapı geçerliği için kullanılan başlıca yöntemlerden birisini oluşturmaktadır (Kline, 2005; Tabachnick ve Fidell, 2001). DFA için Mplus programı sürüm 8.4 kullanılmıştır. Ölçüt bağıntı geçerliği için 
ÇODDÖ Davranış Düzenleme Alt Ölçeği (Sezgin ve Demiriz, 2016) kullanılmıştır. Ölçeğin güvenirliği Cronbach alfa iç tutarlık ve test-tekrar test yöntemleriyle, madde analizi ise düzeltilmiş madde-toplam korelasyonu ve \%27'lik alt üst grup karş1laştırmaları ile incelenmiştir. Bu analizler için ise SPSS 22 programı kullanılmıştır. Ayrıca ÇYDİE’nin alt ölçeklerinden alınan puanların çocukların cinsiyetine ve yaşına göre farklılaşıp farklılaşmadığını incelemek amacıyla bağımsız örneklemler için t-testi kullanılmıştır.

\section{BULGULAR}

\section{Madde Analizi}

ÇDYİE'nin maddelerinin ölçeğin bütününü temsil gücünü ve ayırt ediciliğini belirleyebilmek amacıyla madde toplam korelasyonu incelenmiş ve \%27'lik alt üst grup karşılaştırmaları yapılmıştır. Analiz sonuçları Tablo 2'de verilmiştir.

Tablo 2. ÇDYİE’nin madde toplam korelasyonu ve \%27 alt-üst gruplar arasındaki farkllıklara ait t-testi sonuçları

\begin{tabular}{|c|c|c|c|c|c|c|c|c|}
\hline & \multicolumn{3}{|c|}{ Alt $\% 27$} & \multicolumn{4}{|c|}{ Üst $\% 27$} & \multirow[t]{2}{*}{$\begin{array}{l}\text { Madde Toplam } \\
\text { Korelasyonu }\end{array}$} \\
\hline & $\mathrm{n}$ & $\mathrm{M}$ & $\mathrm{SD}$ & $\mathrm{n}$ & $\mathrm{M}$ & $\mathrm{SD}$ & $\mathrm{t}$ & \\
\hline $\begin{array}{l}\text { Çalişan } \\
\text { Bellek }\end{array}$ & 213 & 1.8 & 0.16 & 209 & 3.12 & 0.53 & $-50.85^{* *}$ & \\
\hline Madde 19 & 201 & 1.00 & 0.00 & 203 & 3.39 & 0.70 & $-48.13^{* *}$ & 0.80 \\
\hline Madde 3 & 204 & 1.00 & 0.00 & 203 & 3.06 & 0.78 & $-37.34 * *$ & 0.74 \\
\hline Madde 20 & 201 & 1.00 & 0.00 & 203 & 3.46 & 0.62 & $-55.94 * *$ & 0.83 \\
\hline Madde 6 & 204 & 1.00 & 0.00 & 203 & 3.55 & 0.68 & $-53.37 * *$ & 0.73 \\
\hline Madde 23 & 196 & 1.00 & 0.00 & 203 & 3.56 & 0.71 & $-50.34 * *$ & 0.70 \\
\hline Madde 1 & 193 & 1.00 & 0.00 & 203 & 3.37 & 0.65 & $-50.68^{* *}$ & 0.77 \\
\hline Madde 9 & 202 & 1.00 & 0.00 & 203 & 2.88 & 0.86 & $-30.96 * *$ & 0.69 \\
\hline Madde 24 & 203 & 1.00 & 0.00 & 203 & 3.39 & 0.59 & $-56.94 * *$ & 0.81 \\
\hline Madde 21 & 200 & 1.00 & 0.00 & 203 & 3.59 & 0.66 & $-55.02^{* *}$ & 0.75 \\
\hline Madde 7 & 198 & 1.00 & 0.00 & 203 & 3.60 & 0.67 & $-54.03 * *$ & 0.70 \\
\hline Madde 14 & 201 & 1.00 & 0.00 & 203 & 3.47 & 0.64 & $-54.17 * *$ & 0.78 \\
\hline Madde 17 & 202 & 1.00 & 0.00 & 203 & 3.52 & 0.71 & $-50.28 * *$ & 0.70 \\
\hline Madde 12 & 203 & 1.00 & 0.00 & 203 & 3.50 & 0.69 & $-51.52 * *$ & 0.72 \\
\hline $\begin{array}{l}\text { Ketleyici } \\
\text { kontrol }\end{array}$ & 209 & 1.41 & 0.28 & 213 & 3.45 & 0.45 & $-55.21 * *$ & \\
\hline Madde 2 & 202 & 1.16 & 0.36 & 203 & 3.96 & 0.64 & $-53.99 * *$ & 0.48 \\
\hline Madde 8 & 201 & 1.19 & 0.39 & 203 & 4.01 & 0.61 & $-55.10^{* *}$ & 0.74 \\
\hline Madde 13 & 237 & 1.02 & 0.16 & 202 & 3.80 & 0.77 & $-53.93 * *$ & 0.72 \\
\hline Madde 4 & 204 & 1.00 & 0.00 & 203 & 3.46 & 0.62 & $-56.35^{* *}$ & 0.69 \\
\hline Madde 15 & 204 & 1.29 & 0.45 & 203 & 4.09 & 0.63 & $-51.12^{* *}$ & 0.71 \\
\hline Madde 18 & 201 & 1.00 & 0.00 & 203 & 3.81 & 0.75 & $-53.10^{* *}$ & 0.75 \\
\hline Madde 11 & 201 & 1.34 & 0.47 & 203 & 4.11 & 0.64 & $-49.60 * *$ & 0.74 \\
\hline Madde 5 & 204 & 1.05 & 0.22 & 203 & 3.72 & 0.72 & $-50.55^{* *}$ & 0.63 \\
\hline Madde 10 & 203 & 1.34 & 0.47 & 203 & 4.48 & 0.50 & $-64.78^{* *}$ & 0.46 \\
\hline Madde 22 & 203 & 1.00 & 0.00 & 202 & 4.00 & 0.73 & $-58.31 * *$ & 0.62 \\
\hline Madde 16 & 203 & 1.00 & 0.00 & 203 & 3.62 & 0.70 & $-53.12 * *$ & 0.65 \\
\hline
\end{tabular}

Yapılan analizler sonucunda, ÇDYİE'deki maddelerin düzeltilmiş madde-toplam korelasyon katsayılarının 0.46 ile 0.83 arasında değiştiği bulunmuştur. Madde toplam korelasyonu değerlerinin 
0.30 ve üzerinde olması yeterli kabul edilmektedir (Büyüköztürk, 2004). Üst \%27 ile alt \%27'lik grupların madde ortalama puanları arasında yapılan t testi sonuçlarına göre, farkların tüm maddeler ve alt ölçek toplam puanları için anlamlı olduğu $(\mathrm{p}<0.001)$ ve t değerlerinin 30.96 ile 64.78 arasında değiştiği gözlemlenmiştir. Bu bulgu, ölçekteki tüm maddelerin ve alt boyutların ayırt edici olduklarını göstermektedir.

\section{Yapı Geçerliği}

\section{Doğrulayıcı faktör analizi}

Ölçeğin 2 faktörlü özgün modelinin kabul edilebilirliğini incelemek için Mplus (Muthen ve Muthen, 2012) kullanılarak 2 faktörlü doğrulayıcı faktör analizi (DFA) ölçüm modeli uygulanmıştır. Buna ek olarak, bu iki faktörlü yapının çocukların yaşlarına göre farklılık gösterip göstermediğini test etmek için DFA modelleri bu iki yaş grubu için Mplus (grouping method) yardımıyla yapılmıştır. Öncelikle modelin mevcut verilere uyumunu test etmek için Karşılaştırmalı Uyum Endeksi (Comparative Fit Index; CFI) (Bentler, 1995), Karekök Artığ1 (RMSEA; Brown ve Cudeck, 1992) ve Standardize Ortalama Karekök Artığ1 (SRMR; Bentler, 1995; Hu ve Bentler, 1999) model uyum endeksleri kullanılmıştır. RMSEA değerleri 0.5 'ten düşük olanların uyum gösterdiği kabul edilirken (Schumacker ve Lomax, 1996) 0.5 ile 0.8 arasındaki değerlerin de kabul edilebilir olduğu düşünülmüştür (Brown ve Cudeck, 1992; MacCallum, Browne ve Sugawara, 1996). CFI değerlerinin 0.9'un üzerinde olması değerlerin kabul edilebilir bir uyum endeksi oluşturduğunu göstermektedir (Çokluk, Şekercioğlu ve Büyüköztürk, 2012; Kline, 2005; Marsh, Balla ve McDonald, 1988). Her ne kadar RMSEA değerleri, 0.8 altında olanlar iyi olarak kabul edilse de 0.10'a kadar olan değerler de kabul edilebilir aralıktadır (Anderson ve Gerbing, 1984; Kline, 2005; MacCallum ve diğerleri, 1996; Marsh ve diğerleri, 1988).

Bu çalışmada öncelikle, tüm örneklem grubu için DFA modeli test edilmiştir. Uyum endekslerine bakıldığında, bu modelin veriler ile iyi bir uyum sağladığı tespit edilmiştir [ $\chi^{2} \quad(544)=1113.891$, $\mathrm{CFI}=0.93, \mathrm{RMSEA}=0.06(\% 90 \mathrm{CI} 06,07)$ ve SRMR $=0.04]$. Buna ek olarak, 4 ve 5 yaş grubunun da içinde bulunduğu modelin de veriler ile iyi bir uyum sağladığ1 tespit edilmiştir $\left[\chi^{2}(544)=\right.$ 1595.225, CFI= 0.91, RMSEA = $0.07(\% 90$ CI 06, 07) ve SRMR=0.05]. Tüm örneklem ve yaş grupları için bulunan DFA yükleri anlamlı olarak, belirlenen alt ölçeklere yüklenmiştir (bkz. Tablo 3).

Tablo 3 incelendiğinde, faktör yük değerlerinin 0.47 ile 0.85 arasında değiştiği görülmektedir. Ayrıca, DFA sonucunda elde edilen tüm örneklem için ÇDYİE diyagram ile gösterimi Şekil 1'de verilmiştir. 
Tablo 3. ÇDYİE doğrulayıcı faktör analiz sonuçları

\begin{tabular}{|c|c|c|c|}
\hline Alt Ölçek & $\begin{array}{l}\text { Toplam Örneklem } \\
N=754\end{array}$ & $\begin{array}{l}48-60 \text { ay } \\
n=319\end{array}$ & $\begin{array}{l}61-72 \text { ay } \\
n=435\end{array}$ \\
\hline Çalışan Bellek & DFA Yükleri $(\alpha=.95)$ & DFA Yükleri $(\alpha=.94)$ & DFA Yükleri $(\alpha=.95)$ \\
\hline Madde 19 & .81 & .80 & .81 \\
\hline Madde 3 & .75 & .73 & .76 \\
\hline Madde 20 & .83 & .81 & .85 \\
\hline Madde 6 & .75 & .73 & .75 \\
\hline Madde 23 & .72 & .68 & .75 \\
\hline Madde 1 & .79 & .75 & .82 \\
\hline Madde 9 & .71 & .67 & .72 \\
\hline Madde 24 & .82 & .79 & .84 \\
\hline Madde 21 & .79 & .76 & .81 \\
\hline Madde 7 & .72 & .71 & .72 \\
\hline Madde 14 & .80 & .78 & .81 \\
\hline Madde 17 & .71 & .68 & .72 \\
\hline Madde 12 & .74 & .71 & .76 \\
\hline Ketleyici kontrol & $(\alpha=.91)$ & $(\alpha=.91)$ & $(\alpha=.90)$ \\
\hline Madde 2 & .52 & .52 & .51 \\
\hline Madde 8 & .80 & .82 & .78 \\
\hline Madde 13 & .76 & .75 & .76 \\
\hline Madde 4 & .74 & .72 & .75 \\
\hline Madde 15 & .75 & .73 & .76 \\
\hline Madde 18 & .78 & .78 & .79 \\
\hline Madde 11 & .78 & .75 & .80 \\
\hline Madde 5 & .65 & .67 & .64 \\
\hline Madde 10 & .48 & .48 & .47 \\
\hline Madde 22 & .65 & .68 & .62 \\
\hline Madde 16 & .67 & .65 & .67 \\
\hline
\end{tabular}

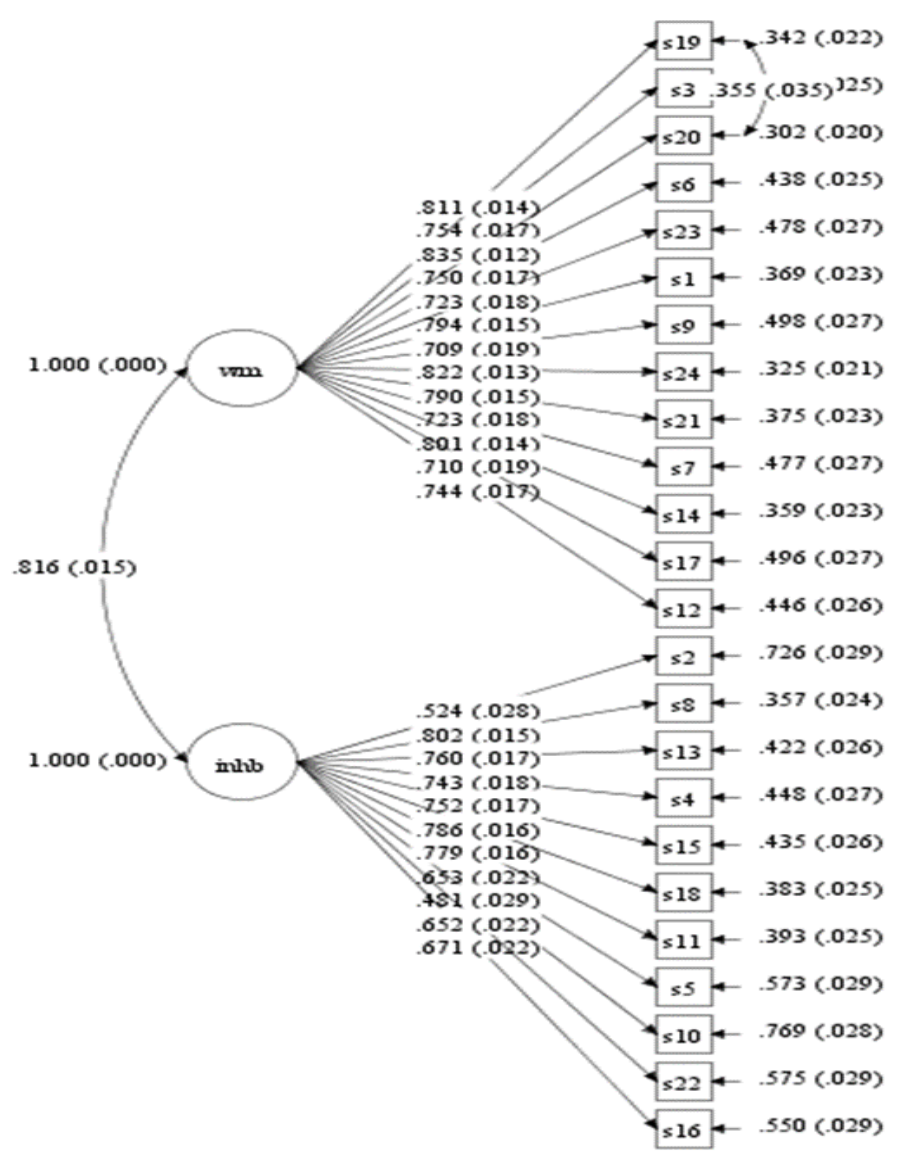

Şekil 1. Tüm örneklem için ÇDYİE diyagram ile gösterimi 


\section{Ölçüt Bağıntılı Geçerlik}

ÇDYİE’nin ölçüt bağıntılı geçerliğini sınamak üzere 98 çocuk için öğretmenleri ÇDYİE ile ÇODDÖ Davranış Düzenleme Alt Ölçeği'ni (Sezgin ve Demiriz, 2016) birlikte doldurmuştur. Öngörüldüğü üzere, ÇODDÖ Davranış Düzenleme puanları ile ÇDYİE Çalışan Bellek (r=0.83, $\mathrm{p}<0.001)$ ve Ketleyici kontrol $(\mathrm{r}=0.77, \mathrm{p}<0.001)$ puanları arasında pozitif yönlü anlamlı korelasyon katsayıları elde edilmiştir (bkz. Tablo 4).

Tablo 4. ÇDYİE ile ÇODDÖ Davranış Düzenleme Alt Ölçeği arasındaki korelasyon katsayıları

\begin{tabular}{ll}
\hline ÇDYİE & ÇODDÖ \\
Alt Ölçekler & Davranış Düzenleme Alt Ölçeği \\
\hline Çalışan Bellek & $.83^{* *}$ \\
Ketleyici kontrol & $.77^{* *}$ \\
$* * \mathrm{p}<.001$ &
\end{tabular}

\section{Güvenirlik}

ÇDYİE'nin güvenirliğini ortaya koymak üzere Cronbach alfa iç tutarlık ve test tekrar test yöntemleri kullanılmıştır. Test-tekrar test güvenirlik çalışmasında 69 çocuk için öğretmenleri iki hafta arayla ölçeği doldurmuşlardır. Analiz sonuçları, Tablo 5’te sunulmuştur.

Tablo 5. ÇDYİE’nin Cronbach Alfa ve test-tekrar test güvenirlik katsayıları

\begin{tabular}{lll}
\hline ÇDYİE Alt Ölçekler & Cronbach Alfa & \\
\hline Çalışan Bellek & $.95^{* *}$ & Test-Tekrar Test $^{2}$ \\
Ketleyici kontrol & $.91^{* *}$ & $.89^{* *}$ \\
${ }^{1} \mathrm{n}=754^{2}{ }^{2} \mathrm{n}=69^{* *} \mathrm{p}<.001$ & & $.85^{* *}$ \\
\hline
\end{tabular}

ÇDYİE’nin alt ölçeklerinin güvenilirliği için hesaplanan Cronbach alfa katsayıları Çalışan Bellek alt ölçeği için 0.95 ve Ketleyici kontrol alt ölçeği için 0.91 olarak bulunmuştur. Ayrıca iki yaş grubunun da iç tutarlık değerleri yine kabul edilebilir seviyede bulunmuştur (bkz. Tablo 3). Test-tekrar test güvenirlik katsayısı ise Çalışan Bellek için 0.89 ve Ketleyici kontrol için 0.85 olarak bulunmuştur. Elde edilen bu sonuçlar ölçeğin güvenirliğinin iyi düzeyde olduğunu göstermektedir.

Bununla birlikte, ÇDYİE alt ölçekler arasındaki korelasyon da hesaplanmış ve Çalışan Bellek ve Ketleyici Kontrol alt ölçeklerinin birbirleriyle arasında pozitif yönlü anlamlı bir korelasyon olduğu bulunmuştur $(\mathrm{r}=0.75, \mathrm{p}<0.001)$.

\section{Yaş ve Cinsiyet Değişkenleri Açısından Farklılıklar}

ÇYDİE alt ölçeklerine ait puanların çocukların cinsiyetine ilişkin olarak farklılaşıp farklılaşmadığı bağımsız örneklemler için t-test kullanılarak incelenmiştir. Buna göre, kız çocuklarının $(M=4.08$, $S D=0.74)$ erkek çocuklarına $(M=3.78, S D=0.83)$ göre çalışan bellek puanları daha yüksektir $[t(746)=5.08, p<0.001, d=0.37]$. Yine kız çocuklarının $(M=3.79, S D=0.77)$ erkek çocuklarına 
$(M=3.41, S D=0.85)$ göre ketleyici kontrol puanlarının da daha yüksek olduğu tespit edilmiştir $[t(747)=6.36, p<0.001, d=0.46]$.

ÇYDİE alt ölçeklerine ait puanların çocukların yaşlarına ilişkin olarak farklılaşıp farklılaşmadığı bağımsız örneklemler için t-test kullanılarak incelenmiştir. Buna göre, 48-66 aylık çocukların $(M=3.76, S D=0.78) 67-72$ aylık çocuklara $(M=4.06, S D=0.79)$ göre çalışan bellek puanları daha düşüktür $[t(752)=5.15, p<0.001, d=0.38]$. Yine 48-66 aylık çocukların $(M=3.45, S D=0.82) 67-$ 72 aylık çocuklara $(M=3.71, S D=0.82)$ göre ketleyici kontrol puanlarının da daha düşük olduğu bulunmuştur $[t(752)=4.26, p<0.001, d=0.31]$.

\section{SONUÇ ve TARTIŞMA}

Küçük çocukların yürütücü işlevlerinin değerlendirilmesine yönelik artan ilgi düşünüldügüünde, yürütücü işlev becerilerini ölçen ölçme araçlarının geliştirilmesi ve uyarlanması önemli bir araştırma önceliği haline gelmiştir. Bu çalışmada, çocukların yürütücü işlevlerinin davranışsal göstergelerini yakalamayı amaçlayan bir ölçek olan ÇYDİE’nin (Thorell ve Nyberg, 2008) Türkçe öğretmen formunun 48-72 aylık çocuklar için geçerlik ve güvenirlik çalışması gerçekleştirilmiştir.

İlk olarak madde analizi yapılmış ve ölçekteki tüm maddelerin ve alt boyutların ayırt edici oldukları tespit edilmiştir. ÇDYİE’nin güvenirliği Cronbach alfa iç tutarlık ve test tekrar test yöntemleriyle hesaplanmıştır. Güvenirliğe yönelik elde edilen sonuçlar ölçeğin iyi düzeyde güvenilir olduğunu göstermektedir.

ÇDYİE’nin yapı geçerliğini ortaya koymak üzere yapılan DFA'ya göre, iki faktörlü modelin gözlemlenen verilere en iyi uyumu sağladığı bulunmuştur. Başka bir deyişle DFA, 4-6 yaş arası küçük çocukların günlük yaşamındaki yürütücü işlevlerin, kontrollü davranışın iki ayrı yönüne ayrılabileceğine dair kanıt sağlamıştır: ketleyici kontrol ve çalışan bellek. Şimdiye kadar, orijinal çalışma da dahil olmak üzere ÇYDİE üzerinde yapılan tüm araştırmalar, iki faktörlü bir yapının verilere iyi uyduğunu bulmuştur (Camerota ve diğerleri, 2018; Catale ve diğerleri, 2013a; Catale ve diğerleri, 2013b; Kayhan, 2010; Thorell ve Nyberg, 2008). Buna göre, farklı yaş ve milletlerden çocukları dahil eden çalışmalar arasındaki bu yüksek düzeydeki uyuşum, 4 ila 12 yaş arası çocuklarda ampirik olarak farklı iki alt ölçeğin (Çalışan Bellek ve Ketleyici kontrol) kullanımını desteklemektedir.

Ölçeğin geçerlik çalışmaları kapsamında ayrıca ölçüt bağıntılı geçerlik yöntemi kullanılmıştır. Bu amaçla, ÇDYİE ile Çocuk Davranış Değerlendirme Ölçeği, Davranış Düzenleme Alt Ölçeği arasındaki ilişkiler incelenmiştir. ÇDYİE ve ÇODDÖ Davranış Düzenleme Alt Ölçeği arasında 
pozitif yönde istatistiksel olarak anlamlı ilişkiler bulunmuştur. Tüm bu sonuçlar ÇDYİE’nin geçerli bir ölçme aracı olduğunu ortaya koymaktadır.

Ayrıca bu çalışmada ÇDYİE'nin ek geçerliğine kanıt olarak, alt ölçek puanlarının çocukların cinsiyetine göre farklılaşıp farklılaşmadığı incelenmiş ve kızların hem çalışan bellek hem de ketleyici kontrol becerilerinde erkeklerden daha yüksek puan gösterdikleri bulunmuştur. Bu sonuç ÇYDİE ile yapılan önceki çalışmalarla uyumludur (Camerota ve diğerleri, 2018; Kayhan, 2010). Ayrıca bu sonuç, düşük gelirli ailelerden gelen erkek çocukların performansa dayalı yürütücü işlev beceri ölçümlerinde daha düşük performans gösterdiğini gösteren önceki araştırmalarla da tutarlıdır (örn., Willoughby ve Blair, 2015). Bununla birlikte, bu çalışmada ÇYDİE alt ölçek puanlarının çocukların yaşına göre farklılaşıp farklılaşmadığı da incelenmiş ve 4 yaş çocuklarının hem çalışan bellek hem de ketleyici kontrol becerilerinde 5 yaş çocuklarına göre daha düşük puan gösterdikleri bulunmuştur. Okul öncesi dönemde yürütücü işlev becerilerinde gözle görülür bir artşs olduğu düşünüldüğünde, bu bulgu ÇYDİE'nin yürütücü işlev becerilerindeki normatif gelişimsel değişikliklere yönelik duyarlılığını yansıtmaktadır (Garon ve diğerleri, 2008). Bu sonuç ÇYDİE ile yapılan önceki çalışmalarla uyumludur (Camerota ve diğerleri, 2018; Kayhan, 2010). Yeni yapılan bir çalışmada da ebeveyn değerlendirmesine göre 3 yaşındakilerin ileri yürütücü işlev göstergesi olan davranışları 5 yaşındakilerden daha az sıklıkta gösterdikleri tespit edilmiştir (Nilsen, Huyder, McAuley ve Liebermann, 2017). Yürütücü işlevleri değerlendirmek için performansa dayalı görevleri kullanan çalışmalarda da benzer bulgular bulunmuştur (örn., Carlson, 2005).

Derecelendirme ölçeklerinin kullanılmasının altında yatan bir varsayım, yürütücü işlevlerin performansa dayalı görevlerde değerlendirilen süreçlerle önemli ölçüde ilişkili davranışları ölçmeleridir (Toplak ve diğerleri, 2013). Ancak, Toplak ve diğerleri (2013) tarafından performansa dayalı görevler ile yürütücü işlevler derecelendirme ölçekleri arasındaki ilişkiyi araştıran bir meta analizde, iki yöntem arasında sadece küçük korelasyonlar bulmuşlardır ve bu nedenle yürütücü işlevler için bu iki değerlendirme yöntemi arasında gözlemlenebilir bir yakınsama geçerliliği olmadığ1 sonucuna varmışlardır. Dolayısıyla, her iki değerlendirme yöntemi de yararlı ve değerlidir, ancak çocukların yürütücü işlevlerine ilişkin farklı bilgi türleri sağlamaktadırlar.

ÇYDİE, çevrimiçi olarak ücretsiz olarak mevcuttur ve diğer derecelendirme ölçeklerinden önemli ölçüde daha kısadır, bu da onu düşük kaynaklı ortamlar için iyi bir seçenek haline getirmektedir. Ayrıca, ÇYDİE'nin faktör yapısı birçok örneklemde tekrarlanmıştır ve ölçüm değişmezliği kanıtı ortaya konmuştur (Camerota ve diğerleri, 2018). ÇYDİE'nin ebeveyn ve öğretmen değerlendirmeleri, çeşitli Avrupa ve Asya kültürlerinden (Thorell, Veleiro, Siu ve Mohammadi, 
2013) çocuklarda akademik başarıyı öngörmektedir ve DEHB olan çocuklar ve tipik olarak gelişen çocuklar arasında iyi bir ayrım yapmaktadır (Catale ve diğerleri, 2013b; Thorell ve diğerleri, 2010). Birlikte ele alındığında, literatür ÇYDİE'nin farklı katılımcılar, kültürler ve yaş gruplarıyla kullanımını desteklemektedir. Bununla birlikte, norm referanslı puanlar henüz geliştirilmediğinden, bir çocuğun puanlarının klinik olarak yükselip yükselmediğine dair çıkarımlarda bulunulamaz.

\section{Öneriler}

Bu çalışmanın sonuçlarının çeşitli faktörlerle sınırlı olduğu kabul edilmektedir. İlk olarak, ÇYDİE için sadece öğretmen yanıtları elde edilmiştir ve bu nedenle bu örnekte bulunan faktör yapısının farklı katılımcılar (yani anne ve baba) için geçerli olacağı teyit edilemez. Bununla birlikte, daha önceki çalışmalar ebeveyn ve öğretmen kaynaklı ÇYDİE puanlarının faktör yapısı açısından benzer şekilde işlev gördügünü bulmuş olsa da (Thorell ve Nyberg, 2008), ileriki çalışmalarda ebeveynlerden alınacak verilerle de faktör yapısını doğrulamak faydalı olacaktır. Ayrıca, bu çalışmada İstanbul'un birçok ilçesinden çeşitli gruplardan çocuklar örneklenmiş olsa da bu bulgular Türkiye'yi bir bütün olarak temsil etmemektedir ve bu yüzden ortalama puanlar sadece tanımlayıcı olarak görülmelidir. Gelecekteki araştırmalar farklı örnekleme yöntemlerini kullanarak okul öncesi dönemdeki çocuklar için norm referanslı puanların daha iyi bir kestirimini sağlayabilir.

Yapısının karmaşıklığı nedeniyle, yürütücü işlevleri tek bir ölçme aracıyla ölçmek mümkün değildir ve derecelendirme ölçekleri ve performansa dayalı görevler okul öncesi çocuklarda yürütücü işlevlerin farklı yönlerine değinmektedir (Laufs, 2018; Toplak ve diğerleri, 2013). Bu yüzden gelecekteki araştırmalar, ÇYDİE ve yürütücü işlevlerin farklı boyutlarını ölçen performansa dayalı görevler arasındaki ilişkileri inceleyebilir ve öğretmen ve ebeveyn değerlendirmeleri ile performans ölçümleri arasındaki farkları ortaya koyabilir.

\section{Sonuç}

Bu çalışmada 2 alt ölçekte toplam 24 maddeden oluşan ÇYDİE Türkçe formunun 48-72 aylık çocukların yürütücü işlev becerilerini değerlendirmede geçerli ve güvenilir bir ölçme aracı olduğu ortaya konmuştur. Ölçeğin kısa, kolay uygulanabilir ve ücretsiz oluşu nedeniyle okul öncesi dönem çocuklarının yürütücü işlev becerilerini incelemeyi amaçlayan gelecekteki araştırmalarda önemli bir ihtiyacı karşılayacağı düşünülmektedir. ÇYDİE hem araştırma hem de klinik ortamlarında kullanılabilir. Ayrıca, yürütücü işlevler ile ilgili risk grubundaki çocukların belirlenmesinde ve müdahale uygulamalarının yönlendirilmesinde kullanılabileceği söylenebilir. 


\section{KAYNAKÇA}

Acar, I. H., Kutaka, T., Rudasill, K. M., Torquati, J., Coplan, R. J., \& Yildiz, S. (2018). Examining the Roles of Child Temperament and Teacher-Child Relationships as Predictors of Turkish Children's Social Competence and Anti-Social Behavior. Current Psychology. Advance online publication. https://doi.org/10.1007/s12144-018-9901-z

Alp, I. E., \& Özdemir, B. Ö. (2007). Çocuklarda akıcı zekanın (Gf) bilgi isleme hızı, kısa süreli bellek ve çalışma belleği kapasitesi ile ilişkisi. Türk Psikoloji Dergisi, 22(60), 1-15.

Anderson, J. C., Gerbing, D. W. (1984). The effect of sampling error on convergence, improper solutions and goodness-of-fit indices for maximum likelihood confirmatory factor analysis. Psychometrika, 49, 155-173.

Barkley, R. A. (1997). ADHD and the nature of self-control. New York: Guilford Press.

Bentler, P. M. (1995). EQS structural equations program manual. Encino, CA: Multivariate Software.

Best, J. R., Miller, P. H., \& Jones, L. L. (2009). Executive functions after age 5: Changes and correlates. Developmental Review, 29, 180-200. http://dx.doi.org/10.1016/j.dr.2009.05.002

Bronson, M. B., Goodson, B. D., Layzer, J. J. \& Love, J. (1990). Child Behavior Rating Scale. Cambridge, M. A.: Abt. Associates.

Bronson, M. B., Tivnan, T., \& Seppanen, P. S. (1995). Relations between teacher and classroom activity variables and the classroom behaviors of pre-kindergarten children in Chapter 1 funded programs. Journal of Applied Developmental Psychology, 16, 253-282. https://doi.org/10.1016/0193-3973(95)90035-7

Browne, M. W. \& Cudeck, R. (1992). Alternative ways of assessing model fit. Sociological Methods and Research, 21, 230-258. DOI:10.1177/0049124192021002005

Büyüköztürk, Ş. (2004). Veri analiæ̣i el kitabı. Ankara: PegemA Yayıncılık.

Camerota, M., Willoughby, M. T, Kuhn, L. J. \& Blair, C. B. (2018). The Childhood Executive Functioning Inventory (CHEXI): Factor structure, measurement invariance, and correlates in US preschoolers. Child Neuropsychology, 24(3), 322-337, DOI: 10.1080/09297049.2016.1247795

Carlson, S. M. (2005). Developmentally sensitive measures of executive function in preschool children. Developmental Neuropsychology, 28, 595-616. http://dx.doi.org/10.1207/s15326942dn2802_3

Carlson, S. M., Zelazo, P. D., \& Faja, S. (2013). Executive function. İçinde Oxford Handbook of Developmental Psychology, Vol. 1 (s. 706-742). doi: 10.1093/oxfordhb/9780199958450.013.0025

Catale, C., Lejeune, C., Merbah, S., \& Meulemans, T. (2013). French adaptation of the Childhood Executive Functioning Inventory (CHEXI): Confirmatory factor analysis in a sample of young French-speaking Belgian children. European Journal of Psychological Assessment, 29(2), 149. https://doi.org/10.1027/1015-5759/a000141 
Catale, C., Meulemans, T., \& Thorell, L. B. (2013). The Childhood Executive Function Inventory: Confirmatory factor analyses and cross-cultural clinical validity in a sample of 8-to 11-yearold children. Journal of Attention Disorders, 19(6), 489-495. DOI:10.1177/1087054712470971

Collette, F., Van der Linden, M., Laureys, S., Delfiore, G., Degueldre, C., Luxen, A., vd. (2005). Exploring the unity and diversity of the neural substrates of executive functioning. Human Brain Mapping, 25, 409-423. https://doi.org/10.1002/hbm.20118

Çokluk, Ö., Şekercioğlu, G. ve Büyüköztürk, Ş. (2012). Sosyal bilimler için çok değğskenli istatistik: SPSS ve Lisrel uygulamalar (2. Baskı). Ankara: Pegem Akademi.

Davidson, M. C., Amso, D., Anderson, L. C., \& Diamond, A. (2006). Development of cognitive control and executive functions from 4 to 13 years: Evidence from manipulations of memory, inhibition, and task switching. Neuropsychologia, 44(11), 2037-2078. https://doi.org/10.1016/j.neuropsychologia.2006.02.006

Davis, H. L. ve Pratt, C. (1995). The development of children's theory of mind: The working memory explanation. Australian Journal of Psychology, 47(1), 25-31. https://doi.org/10.1080/00049539508258765

Denckla, M. B. 2002. The Behavior Rating Inventory of Executive Function: Commentary. Child Neuropsychology, 8, 304-306. https://doi.org/10.1076/chin.8.4.304.13512

Diamond, A. (2012). Activities and programs that improve children's executive functions. Current Directions in Psychological Science, 21, 335-341. doi:10.1177/0963721412453722

Diamond, A. (2013). Executive functions. Annual Review of Psychology, 64, 135-168. DOI:10.1146/annurev-psych-113011-143750

Diamond, A. (2016). Why improving and assessing executive functions early in life is critical. Içinde J. A. Griffin, P. McCardle, \& L. Freund (Eds.), Executive function in preschool-age children: Integrating measurement, neurodevelopment, and translational research (s. 11-43). Washington, DC: American Psychological Association.

Doebel, S., \& Zelazo, P. D. (2015). A meta-analysis of the Dimensional Change Card Sort: Implications for developmental theories and the measurement of executive function in children. Developmental Review, 38, 241-268. https://doi.org/10.1016/j.dr.2015.09.001

Erdoğan Bakar, E., Taner, Y.I., Soysal, A. Ş., Karakaş, S., \& Turgay, A. (2011) Behavioral Rating Inventory and Laboratory Tests Measure Different Aspects of Executive Functioning in Boys: A Validity Study. Bulletin of Clinical Psychopharmacology, 21(4), 302-316, DOI: 10.5455/bcp.20111004014003

Garon, N., Bryson, S. E., \& Smith, I. M. (2008). Executive function in preschoolers: A review using an integrative framework. Psychological Bulletin, 134, 31-60. http://dx.doi.org/10.1037/0033-2909.134.1.31

Gerstadt, C. L., Hong, Y. J., \& Diamond, A. (1994). The relationship between cognition and action: performance of children 31/2-7 years old on a Stroop-like day-night test. Cognition, 53(2), 129-153. https://doi.org/10.1016/0010-0277(94)90068-X 
Gioia, G., Espy, K., \& Isquith, P. (2003). Behavior Rating Inventory of Executive Function- Preschool version professional manual. Luzt, FL: Psychological Assessment Resources.

Gioia, G. A., Isquith, P. K., Guy, S. C., \& Kenworthy, L. (2000). Behavior rating inventory of executive function. Odessa, Florida: Psychological Assessment Resources.

Griffin, J. A., Freund, L., McCardle, P., DelCarmen-Wiggins, R., \& Haydon, A. (2016). Introduction to executive function in preschool-age children. İçinde J. A. Griffin, P. McCardle, \& L. Freund (Eds.), Executive function in preschool-age children: Integrating measurement, neurodevelopment, and translational research (s. 3-7). Washington, DC: American Psychological Association.

Hendry, A., Jones, E. J. H., \& Charman, T. (2016). Executive function in the first three years of life: Precursors, predictors, and patterns. Developmental Review, 42, 1-33. http://dx.doi.org/10.1016/j.dr.2016.06.005

Hu, L. T., \& Bentler, P. M. (1999). Cut-off criteria for fit indexes in covariance structure analysis: Conventional criteria versus new alternatives. Structural Equation Modeling, 6, 1-55. https://doi.org/10.1080/10705519909540118

Hughes, C. (2011). Changes and challenges in 20 years of research into the development of executive functions. Infant and Child Development, 20(3), 251-271. DOI: 10.1002/icd.736

Hughes, C., Ensor, R., Wilson, A. \& Graham, A. (2010). Tracking executive function across the transition to school: A latent variable approach. Developmental Neuropsychology, 35(1), 20-36. DOI:10.1080/87565640903325691

Huizinga, M., \& Smidts, D. P. (2011) Age-related changes in executive function: A normative study with the Dutch Version of the Behavior Rating Inventory of Executive Function (BRIEF). Child Neuropsychology, 17(1), 51-66. DOI: 10.1080/09297049.2010.509715

Isquith, P. K., Roth, R. M., \& Gioia, G. (2013). Contribution of rating scales to the assessment of executive functions. Applied Neuropsychology: Child, 2, 125-132. DOI:10.1080/ 21622965.2013.748389

Kayhan, E. (2010). A validation study for the Childhood Executive Functioning Inventory: Behavioral correlates of executive functioning. (Yayımlanmamış Yüksek Lisans Tezi). Boğaziçi Üniversitesi, İstanbul.

Kline, R. B. (2005). Principles and practice of structural equation modeling. The Guilford Press: New York, London.

Laufs, R. M. (2018). Development of executive function in typically-developing preschoolers in relation to motor skill development. (Yayımlanmamıs doktora tezi). Heidelberg University Faculty of Behavioural and Cultural Studies, Almanya.

Marsh, H. W., Balla, J. R., \& McDonald, R. P. (1988). Goodness-of-fit indexes in confirmatory factor analysis: the effect of sample size. Psychological Bulletin, 103, 391-410. https://psycnet.apa.org/doi/10.1037/0033-2909.103.3.391

MacCallum, R. C., Browne, M. W., \& Sugawara, H. M. (1996). Power analysis and determination of sample size for covariance structure modeling. Psychological Methods, 1, 130-149. 
McClelland, M. M., \& Cameron, C. E. (2012). Self-regulation in early childhood: Improving conceptual clarity and developing ecologically valid measures. Child Development Perspectives, 6(2), 136-142. https://doi.org/10.1111/j.1750-8606.2011.00191.x

McClelland, M. M., Cameron, C. E., Duncan, R., Bowles, R. P., Acock, A. C., Miao, A., \& Pratt, M. E. (2014). Predictors of early growth in academic achievement: The Head-ToesKnees-Shoulders task. Frontiers in Psychology, 5, 1-14. http://dx.doi.org/10.3389/fpsyg.2014.00599.

McClelland, M. M., Cameron, C. E., Wanless, S. B., \& Murray, A. (2007). Executive function, behavioral self-regulation, and social-emotional competence. İçinde O. N. Saracho \& B. Spodek (Eds.), Contemporary perspectives on social learning in early childhood education (s. 83-107). Greenwich, CT: Information Age.

McMillan, J. H. \& Schumacher, S. (2006). Research in education: Evidence based inquiry. Boston: Brown and Company.

McNab, F., Leroux, G., Strand, F., Thorell, L., Bergman, S., \& Klingberg, T. (2008). Common and unique components of inhibition and working memory: An fMRI, within-subjects investigation. Neuropsychologia, 46, 2668-2682. https://doi.org/10.1016/j.neuropsychologia.2008.04.023

Meuwissen, A. S., \& Zelazo, P. D. (2014). Hot and cool executive function: foundations for learning and healthy development. Zero to Three, 35(2), 18-23.

Miyake, A., Friedman, N. P., Emerson, M. J., Witzki, A. H., Howerter, A., \& Wager, T.D. (2000). The unity and diversity of executive functions and their contributions to complex frontal lobe tasks: A latent variable analysis. Cognitive Psychology, 41, 49-100. http://dx.doi.org/10.1006/cogp.1999.0734

Muthen, L. K. \& Muthen, B. O. (2012). Mplus user's guide (7.bask1). Los Angeles, CA: Muthen \& Muthen.

Neitzel, J. (2018) What measures of program quality tell us about the importance of executive function: Implications for teacher education and preparation. Journal of Early Childhood Teacher Education, 39(3), 181-192. DOI: 10.1080/10901027.2018.1457580

Nguyen, T., \& Duncan, G. J. (2019). Kindergarten components of executive function and third grade achievement: A national study. Early Childhood Research Quarterly, 46, 49-61. https://doi.org/10.1016/j.ecresq.2018.05.006

Nilsen, E. S., Huyder, V., McAuley, T., \& Liebermann, D. (2017). Ratings of Everyday Executive Functioning (REEF): A parent-report measure of preschoolers' executive functioning skills. Psychological Assessment, 29(1), 50-64. http://dx.doi.org/10.1037/pas0000308

Oğuz, N., \& Kara, H. Ş. (2018). 54-66 aylık çocuklarda olumlu sosyal yalan davranışı ile zihin kuramı ve yönetici işlevlerin bağlantıları. Psikoloji Calışmalar, 38(2), 129-154. DOI: $10.26650 /$ SP398724 
Öğütcen, A. (2020). Okul öncesi dönem çocuklarmm yürütücü işlev becerileri ve geometrik sekeil algzlarmm incelenmesi. (Yayımlanmamış doktora tezi). Hacettepe Üniversitesi Eğitim Bilimleri Enstitüsü, Ankara.

Ponitz, C. C., McClelland, M. M., Matthews, J. S., \& Morrison, F. J. (2009). A structured observation of behavioral self-regulation and its contribution to kindergarten outcomes. Developmental psychology, 45(3), 605-619. doi: 10.1037/a0015365.

Rothbart, M. K., Ahadi, S. A., Hershey, K. L., \& Fisher, P. (2001). Investigation of temperament at three to seven years: The Children's Behavior Questionnaire. Child Development, 72 (5), 1394-408. https://doi.org/10.1111/1467-8624.00355

Roth, R. M., Isquith, P. K., \& Gioia, G. A. (2005). Behavior Rating Inventory of Executive Function Adult Version (BRIEF-A). Lutz, FL: Psychological Assessment Resources.

Schumacker, R. E., \& Lomax, R. G. (1996). A beginner's guide to structural equation modeling. Mahwah, New Jersey: Lawrence Erlbaum Associates, Publishers.

Senn, T., Espy, K. A., \& Kaufmann, P. (2004). Using path analysis to understand executive function organization in preschool children. Developmental Neuropsychology, 26(1), 445-464. DOI:10.1207/s15326942dn2601_5

Sezgin, E., Demiriz, S. (2016). Çocuk Davranış Değerlendirme Ölçeği’nin (ÇODDÖ) Türkçe’ye uyarlanması: Geçerlik ve güvenirlik çalışması. Mersin Üniversitesi Eğitim Fakültesi Dergisi, 12(2), 702-718. DOI: 10.17860/efd.15303

Sezgin, E., \& Demiriz, S. (2019) Effect of play-based educational programme on behavioral selfregulation skills of 48-60-month-old children. Early Child Development and Care, 189(7), 11001113, DOI: $10.1080 / 03004430.2017 .1369972$

Steenbergen-Hu, S., Olszewski-Kubilius, P., \& Calvert, E. (2017), PROTOCOL: The direct and indirect effects of school-based executive function interventions on children and adolescents' executive function, academic, social-emotional, and behavioral outcomes: A systematic review. Campbell Systematic Reviews, 13, 1-63. DOI:10.1002/CL2.185

Tabachnick, B. G., \& Fidell, L. S. (2001). Using multivariate statistics (4.baskı). Boston: Allyn and Bacon.

Thorell, L. B., \& Nyberg, L. (2008). The Childhood Executive Function Inventory (CHEXI): A new rating instrument for parents and teachers. Developmental Neuropsychology, 33, 536-552. DOI:10.1080/87565640802101516

Thorell, L. B., Eninger, L., Brocki, K. C., \& Bohlin, G. (2010). Childhood Executive Function Inventory (CHEXI): A promising measure for identifying young children with ADHD? Journal of Clinical and Experimental Neuropsychology, 32, 38-43. DOI:10.1080/13803390902806527

Thorell, L. B., \& Catale, C. (2014). The assessment of executive functioning using the Childhood Executive Functioning Inventory (CHEXI). İçinde Handbook of executive functioning (s. 359366). New York, NY: Springer. 
Thorell, L. B., Veleiro, A., Siu, A. F., \& Mohammadi, H. (2013). Examining the relation between ratings of executive functioning and academic achievement: Findings from a cross-cultural study. Child Neuropsychology, 19, 630-638. doi:10.1080/09297049.2012.727792

Toplak, M. E., West, R. F., \& Stanovich, K. E. (2013). Practitioner review: Do performance-based measures and ratings of executive function assess the same construct? Journal of Child Psychology and Psychiatry, 54(2), 131-143. DOI:10.1111/jcpp.12001

Tuncer, N. (2018). Okul öncesi çocuklarnm yürütücü işlevlerinin gelişimini desteklemeye yönelik ögrretmen eğitim programmın etkililiğinin incelenmesi. (Yayımlanmamış doktora tezi). Gazi Üniversitesi Eğitim Bilimleri Enstitüsü, Ankara.

Wanless, S. B., McClelland, M. M., Acock, A. C., Chen, F.-M., \& Chen, J.-L. (2011). Behavioral regulation and early academic achievement in Taiwan. Early Education \& Development, 22(1), 1- 28. https://doi.org/10.1080/10409280903493306

Willoughby, M. T., \& Blair, C. B. (2015). Longitudinal measurement of executive function in preschoolers. İçinde J. A. Griffen, P. McCardle, \& L. Freund (Eds.), Executive function in preschool age children: Integrating measurement, neurodevelopment, and translational research. Washington, DC: American Psychological Association.

Willoughby, M. T., Blair, C. B., Wirth, R. J., Greenberg, M., \& The Family Life Project Investigators (2012). The measurement of executive function at age 5: Psychometric properties and relationship to academic achievement. Psychological Assessment, 24, 226-239. DOI: $10.1037 / \mathrm{a} 002536$

Yıldız, T., \& Akbaş, T. (2017). Boyut değiştirerek eşleme görevinde boyutlar aynı objenin sıfatları olursa üç yaş çocuklarının performansı artar mı? Psikoloji Çalısmalarn Dergisi, 37(2), 93-108.

Zelazo, P. D., Blair, C. B., \& Willoughby, M. T. (2016). Executive function: Implications for education (NCER 2017-2000). Washington, DC: National Center for Education Research, Institute of Education Sciences, U.S. Department of Education.

Zelazo, P. D., \& Carlson, S. M. (2012). Hot and cool executive function in childhood and adolescence: Development and plasticity. Child Development Perspectives, 6(4), 354-360. https://doi.org/10.1111/j.1750-8606.2012.00246.x 


\section{EK 1}

\section{ÇOCUKLUK DÖNEMI YÜRÜTÜCÜ ISŞLEV ENVANTERI ÖĞRETMEN FORMU}

Aşağıda, bir dizi ifadeler bulacaksınız. Lütfen, her ifadeyi dikkatlice okuyunuz ve sonra o ifadenin doldurduğunuz çocuk için ne kadar doğru olduğunu belirtiniz. Cevabınızı, her ifadeden sonra yer alan sayılardan (1'den 5'e kadar) birini daire içine alarak gösteriniz. Lütfen her soruya yanıt verdiğinizden emin olunuz. Katılımınız için teşekkür ederiz.

\begin{tabular}{|c|c|c|c|c|}
\hline $\begin{array}{c}\text { Kesinlikle } \\
\text { doğru değil }\end{array}$ & $\begin{array}{c}\text { Doğru } \\
\text { değil }\end{array}$ & $\begin{array}{c}\text { Kısmen } \\
\text { doğru }\end{array}$ & Doğru & $\begin{array}{c}\text { Kesinlikle } \\
\text { doğru }\end{array}$ \\
\hline 1 & 2 & 3 & 4 & 5 \\
\hline
\end{tabular}

\begin{tabular}{|c|c|c|c|c|c|}
\hline 1. Uzun talimatları hatırlamakta zorluk yaşar. & 1 & 2 & 3 & 4 & 5 \\
\hline $\begin{array}{l}\text { 2. Yapmak istemediği bir şeyi yapmak konusunda kendini nadiren } \\
\text { motive edebilir. }\end{array}$ & 1 & 2 & 3 & 4 & 5 \\
\hline $\begin{array}{l}\text { 3. Bir etkinliğin ortasındayken, ne yapıyor olduğunu hatırlamada } \\
\text { zorluk yaşar. }\end{array}$ & 1 & 2 & 3 & 4 & 5 \\
\hline $\begin{array}{l}\text { 4. Yapması için bir ödül vaat edilmezse, daha az ilgisini çeken } \\
\text { görevleri tamamlamakta zorluk yaşar. }\end{array}$ & 1 & 2 & 3 & 4 & 5 \\
\hline $\begin{array}{l}\text { 5. İlk olarak ne olabileceği hakkında düşünmeden bir şeyleri yapma } \\
\text { eğilimi vardır. }\end{array}$ & 1 & 2 & 3 & 4 & 5 \\
\hline $\begin{array}{l}\text { 6. Birkaç işi yapması istenildiğinde sadece ilk veya sonuncu olarak } \\
\text { yapılması isteneni hatırlar. }\end{array}$ & 1 & 2 & 3 & 4 & 5 \\
\hline $\begin{array}{l}\text { 7. Takıldığı zamanlarda, bir sorunu farklı yollarla çözmekte zorluk } \\
\text { yaşar. }\end{array}$ & 1 & 2 & 3 & 4 & 5 \\
\hline $\begin{array}{l}\text { 8. Bir işin yapılması gerektiğinde, sıklıkla, daha ilgi çekici bir } \\
\text { şeyden dolayı dikkati dağılır. }\end{array}$ & 1 & 2 & 3 & 4 & 5 \\
\hline 9. Gidip alması istenen şeyi kolayca unutur. & 1 & 2 & 3 & 4 & 5 \\
\hline $\begin{array}{l}\text { 10. Özel bir durum (örn; okul gezisine gitmek, bir eğlenceye gitmek } \\
\text { vb.) olacağı zaman aşırı derecede heyecanlanır. }\end{array}$ & 1 & 2 & 3 & 4 & 5 \\
\hline 11. S1kıcı bulduğu işleri yapmada belirgin zorluk yaşar. & 1 & 2 & 3 & 4 & 5 \\
\hline $\begin{array}{l}\text { 12. Bir etkinliği planlamada zorluk yaşar (Örn; okul gezisi veya okul } \\
\text { için gerekli olan malzemeleri getirmeyi hatırlamak gibi). }\end{array}$ & 1 & 2 & 3 & 4 & 5 \\
\hline $\begin{array}{l}\text { 13. Söylenilmesine rağmen, kendini tutmakta veya zapt etmekte } \\
\text { zorluk yaşar. }\end{array}$ & 1 & 2 & 3 & 4 & 5 \\
\hline $\begin{array}{l}\text { 14. Birçok adımdan oluşan etkinlikleri devam ettirmekte zorluk } \\
\text { yaşar (Örn; küçük çocuklar için, hatırlatılmadan tüm kıyafetlerini } \\
\text { giyebilmek; büyük çocuklar için, tüm ev ödevlerini kendi başına } \\
\text { yapabilmek). }\end{array}$ & 1 & 2 & 3 & 4 & 5 \\
\hline
\end{tabular}




\begin{tabular}{|l|c|c|c|c|c|}
\hline $\begin{array}{l}\text { 15. Konsantre olabilmesi (dikkatini verebilmesi) için verilen görevi } \\
\text { ilgi çekici bulması gerekir. }\end{array}$ & 2 & 3 & 4 & 5 \\
\hline $\begin{array}{l}\text { 16. Uygun olmayan durumlarda, gülümsememek veya gülmemek } \\
\text { için kendini tutmakta zorlanır. }\end{array}$ & 1 & 3 & 4 & 5 \\
\hline $\begin{array}{l}\text { 17. Başkalarının kolayca anlayacağı şekilde, olmuş bir olay } \\
\text { hakkında hikâye anlatmakta zorlanır. }\end{array}$ & 1 & 2 & 4 & 5 \\
\hline $\begin{array}{l}\text { 18. Durdurulması söylendikten hemen sonra bir etkinliği } \\
\text { durdurmakta zorlanır. Örneğin, durdurması istendikten sonra } \\
\text { birkaç kez daha zıplar veya bilgisayarda bir süre daha oynar. }\end{array}$ & 1 & 2 & 3 & 4 & 5 \\
\hline $\begin{array}{l}\text { 19. Nasıl yapıldığı ayrıca gösterilmediği sürece sözlü talimatları } \\
\text { anlamakta zorlanır. }\end{array}$ & 1 & 2 & 3 & 4 & 5 \\
\hline 20. Birkaç adımı içeren işlerde ya da etkinliklerde zorluk yaşar. & 1 & 2 & 3 & 4 & 5 \\
\hline $\begin{array}{l}\text { 21. İleriyi düşünme veya deneyimlerinden ders çıkarmada zorluk } \\
\text { yaşar. }\end{array}$ & 1 & 2 & 3 & 4 & 5 \\
\hline $\begin{array}{l}\text { 22. Bir grup içinde, diğer çocuklar ile karşılaştırıldığında daha haşarı } \\
\text { şekilde davranır (Örn; Bir doğum günü partisinde veya grup } \\
\text { etkinliği sırasında). }\end{array}$ & 1 & 2 & 3 & 4 & 5 \\
\hline $\begin{array}{l}\text { 23. Geriye doğru sayma gibi zihinsel çaba gerektiren görevleri } \\
\text { yapmakta zorlanır. }\end{array}$ & 1 & 2 & 3 & 4 & 5 \\
\hline 24. Bir işle uğraşırken başka şeyleri aklında tutmakta zorlanır. & 1 & 2 & 3 & 4 & 5 \\
\hline
\end{tabular}

Her soruyu cevapladığınızdan emin olunuz. Katılımınız için teşekkür ederiz. 